\title{
UTILIZATION OF DIGESTED SEWAGE SLUDGE IN LACTIC ACID FERMENTATION
}

\author{
Daniel Pleissner ${ }^{1,2, \star}$, Clemens Krieg ${ }^{1}$ and Jan Christoph Peinemann ${ }^{1}$ \\ ${ }^{1}$ Sustainable Chemistry (Resource Efficiency), Institute of Sustainable and Environmental Chemistry, Leuphana University of Lüneburg, \\ Universitätsallee 1, C13.203, 21335 Lüneburg, Germany \\ ${ }^{2}$ Institute for Food and Environmental Research e. V., Papendorfer Weg 3, 14806 Bad Belzig, Germany
}
Article Info:
Received:
27 August 2020
Revised:
23 November 2020
Accepted:
11 December 2020
Available online:
26 Februrary 2021
Keywords:
Sewage sludge
Nitrogen source
Hydrolysis
Lactic acid

\begin{abstract}
The management of sewage sludge is mostly limited to anaerobic digestion, incineration of digestate and recovery of phosphorous. In terms of resource efficiency, it is recommended to make use of the potential of all organic compounds. Nitrogen compounds, for instance, can find application as nutrients in biotechnological processes. To follow this approach, sewage sludge collected after anaerobic digestion, which had carbon and nitrogen contents of $35.9 \%(\mathrm{w} / \mathrm{w})$ and $5.6 \%(\mathrm{w} / \mathrm{w})$, respectively, was first hydrolyzed using $0-1 \%(\mathrm{w} / \mathrm{w})$ sulphuric acid for 15 minutes at $121^{\circ} \mathrm{C}$ and the hydrolysate used as nitrogen source in lactic acid fermentation. Even though the focus was on a recovery of nitrogen compounds, the hydrolytic treatment with $1 \%(\mathrm{v} / \mathrm{v})$ sulphuric acid resulted in a release of $28 \mathrm{mg} \mathrm{g}^{-1}$ glucose. Because of the complex composition of the obtained hydrolysate it was not possible to quantify the released organic nitrogen compounds. Lactic acid fermentations, however, revealed that the concentration of organic nitrogen compounds was sufficient to efficiently convert $10 \mathrm{~g} \mathrm{~L}^{-1}$ of added glucose into $9 \mathrm{~g} \mathrm{~L}^{-1}$ lactic acid, and thus it is expected that digested sewage sludge may be an alternative nitrogen source in lactic acid fermentation, possibly combined with the utilization of a carbon-rich feedstock. Such a utilization approach goes beyond the conventional management strategies of digestated sewage sludge and allows a material utilization even after anaerobic digestion.
\end{abstract}

\section{INTRODUCTION}

Germany produced around 3 million tons of sewage sludge in 2016. Most of it was anaerobically digested followed by incineration or other thermal treatment (Schnell et al., 2020). Despite the development regarding a materially use of sewage sludge during the last years it is state-ofthe-art in wastewater treatment plants to anaerobically digest it for biogas and eventually energy generation (AgaboGarcía et al., 2019). Alternative possibilities are the use of carbon compounds in sewage sludge in the co-fermentation with grass residues (Yang \& Wang, 2019), fallen leaves (Hu \& Wang, 2019) or ryegrass (Yang \& Wang, 2017) for hydrogen production. Furthermore, activated sludge from secondary clarifier of a sewage treatment plant ( $\mathrm{Li}$ et al., 2018) or from a sewage disposal plant (Ma et al., 2014) has been used in microbial lactic acid formation and for the formation of short-chain fatty acids via acidogenic fermentation (Liu et al., 2020).

Anaerobically digested sewage sludge is rich in phosphorous (15-40 $\mathrm{mg} \mathrm{g}^{-1} \mathrm{P}_{2} \mathrm{O}_{5}$ ) and nitrogen (16-60 $\mathrm{mg} \mathrm{g}^{-1}$ ) (Metcalf, 1991). While phosphorous recovery is mandatory for sewage sludge with a content above $20 \mathrm{mg} \mathrm{g}^{-1}$ and can be achieved by struvite formation after anaerobic digestion (Raheem et al., 2018) or from ash after incineration (Günther et al., 2018), recovery or use of nitrogen compounds has not been considered. In 2020, the new German fertilizer ordinance came into force with the aim to reduce the emission of nitrogen and phosphorus from arable land to water bodies. The new ordinance challenges the application of (digested) sewage sludge as it is usually not incorporated into soil within 4 hours, a prerequisite for fertilizer application. In a value chain where carbon and phosphorus compounds in sewage sludge are used or recovered for energy and fertilizer generation, respectively, nitrogen compounds remain unused which may be used as nitrogen source in biotechnological processes, such as lactic acid fermentation.

Lactic acid has a moderate value. Its applicability, however, illustrates the relevance for food and chemical industries, where it is often used as a preservative or for the synthesis of the biopolymer poly(lactic acid), respectively (Juturu \& Wu, 2016; Klotz et al., 2016). The applicability of lactic acid thereby originates from its properties as 
an a-hydroxy acid. It can be polymerized by forming ester bonds between lactic acid molecules to form poly(lactic acid) (Masutani and Kimura, 2015). Lactic acid is efficiently formed by microorganism. Under homofermentative conditions 1 mole glucose results in 2 moles lactic acid (Pleissner, 2019) and serves due to its acidic characteristics as natural conserving agent. When obtained from fossil-oil, lactic acid forms a racemate, while its homofermentative production allows the production of either the D- or L-enantiomeric form (van Velthuijsen, 1996).

Due to the increasing interest of industry in lactic acid, fermentations fed with cost-efficient organic residues or waste streams have been investigated. It was shown that carbon compounds from agricultural residues (Alves de Oliveira et al., 2019; Glaser \& Venus, 2018), organic municipal solid waste (López-Gómez et al., 2020), food waste (Peinemann et al., 2020) or activated sewage sludge (Li et al., 2018; Ma et al., 2014) can be utilized by microbes to produce lactic acid. The activity of microbes also requires the presence of utilizable nitrogen compounds, and thus alternative nitrogen sources, such as green biomass (Dietz et al., 2016) and protein hydrolysate from municipal solid waste (Izaguirre et al., 2020), were investigated as well. To combine waste management and waste utilization, aim of this short communication was to make nitrogen compounds available from DSS to open new utilization paths for this underutilized material.

\section{MATERIAL AND METHODS}

\subsection{Digested sewage sludge}

DSS was collected from the wastewater treatment plant in Lüneburg (Germany) in April 2018 and used for experiments between May and July 2018. The composition of DSS is shown in results and discussion.

\subsection{Inoculum}

Inoculum consisted of an indigenous consortium isolated from food waste. The food waste was collected from Leuphana University canteen in April 2018. It consisted of uneaten food, such as vegetables, meat and noodles. After blending, food waste was fermented at $\mathrm{pH} 6$ and $35^{\circ} \mathrm{C}$ in a bioreactor (ELOFERM, Germany) for 48 hours. Samples were taken regularly, centrifuged for 5 minutes at $4,000 \mathrm{~g}$ and applied as inoculum for lactic acid fermentations.

\subsection{Hydrolysis of digested sewage sludge}

For screening of appropriate sulphuric acid concentration for acid-catalyzed hydrolysis of DSS to make nitrogen sources available for lactic acid fermentation, $150 \mathrm{~g}$ DSS was resuspended in $100 \mathrm{~mL}$ demineralized water. Concentrated sulphuric acid $(98 \%, \mathrm{v} / \mathrm{v}, 0,0.1,0.2,0.5$ or $1 \mathrm{~mL})$ was added to the different approaches $(A-E)$, resulting in a final sulphuric acid concentration of $0,0.1,0.2,0.5$ or $1 \%(\mathrm{v} / \mathrm{v})$, respectively (Martín et al., 2019). Afterwards, suspensions were heated for 15 minutes at $121^{\circ} \mathrm{C}$ to enhance acid-catalyzed hydrolysis followed by a centrifugation at $4,000 \mathrm{~g}$ for 5 minutes after cooling to $20^{\circ} \mathrm{C}$. Supernatants were removed and the $\mathrm{pH}$ set to 6 using $2 \mathrm{M} \mathrm{NaOH}$.

For fermentation purpose, $467.2 \mathrm{~g}$ DSS was resuspen- ded in $300 \mathrm{~mL}$ demineralized water and the volume of concentrated sulphuric acid added which was found appropriate for nutrient release. The suspension was treated as described above.

\subsection{Fermentation}

Fermentation 1 was conducted twice in $100 \mathrm{~mL}$ flasks containing $30 \mathrm{~mL}$ hydrolysate at a temperature of $35^{\circ} \mathrm{C}$ and shaken at $160 \mathrm{rpm}$ on an orbital shaker for 48 hours. Initial pH was 6.8 and kept uncontrolled during fermentation. As carbon source $10 \mathrm{~g} \mathrm{~L}^{-1}$ glucose was added. A $5 \%$ $(\mathrm{v} / \mathrm{v})$ inoculum was used. Beside the actual fermentation, a control fermentation without hydrolysate was conducted once where $30 \mathrm{~mL}$ water was used instead of hydrolysate. Flasks, hydrolysate and water were autoclaved at $121^{\circ} \mathrm{C}$ for 15 minutes prior to experiments. Samples were taken regularly, centrifuged at $4,000 \mathrm{~g}$ for 5 minutes and stored at $-20^{\circ} \mathrm{C}$ until analysis.

To assess the impact of $\mathrm{pH}$ on performance, fermentation 2 was conducted twice using $500 \mathrm{~mL}$ DSS hydrolysate at a set pH of 6 and a temperature of $35^{\circ} \mathrm{C}$ in a bioreactor (ELOFERM, Germany) for 28 hours. Stirring was conducted using a magnetic bar at $200 \mathrm{rpm}$. As carbon source $10 \mathrm{~g}$ $\mathrm{L}^{-1}$ glucose was added. Hydrolysate and reactor were autoclaved at $121^{\circ} \mathrm{C}$ for 15 minutes prior to experiment. $\mathrm{pH}$ was kept constant by automatically adding $2 \mathrm{M} \mathrm{HCl}$ or $2 \mathrm{M}$ $\mathrm{NaOH}$. A 5\% (v/v) inoculum was used. Samples were taken regularly, centrifuged at $4,000 \mathrm{~g}$ for 5 minutes and stored at $-20^{\circ} \mathrm{C}$ until analysis.

\subsection{Analytics}

To determine the dry matter of DSS an aliquot was weighed and dried at $105^{\circ} \mathrm{C}$ until constant weight (Dupré et al., 2020).

Organic matter was quantified by heating $1 \mathrm{~g}$ dry DSS for 4 hours at $575^{\circ} \mathrm{C}$ in a muffle furnace and weighing the remainder (Dupré et al., 2020).

Protein, cellulose and hemicellulose contents were quantified in dried DSS by near infrared spectroscopy (NIR) using a NIR-spectrometer (Unity Scientific GmbH, Weiler bei Bingen, Germany).

Total carbon $(\mathrm{C})$ and nitrogen $(\mathrm{N})$ contents of dried DSS were measured with an elemental $\mathrm{CN}$ analyzer at $1150^{\circ} \mathrm{C}$ (Elementaranalysator vario Max $\mathrm{CN}$ ).

Ammonium quantification was based on the phenol hypochlorite assay (Berthelot reaction) described in Vega-Mas et al. (2015).

Phosphate concentration was determined photometrically via generation of molybdenum blue. At first, four separate solutions were prepared: (I) Sulfuric acid (2.5 M), (II) potassium antimonyl tartrate solution (1.3715 g K(SbO) $\mathrm{C}_{4} \mathrm{H}_{4} \mathrm{O}_{6} \times 1 / 2 \mathrm{H}_{2} \mathrm{O}$ in $500 \mathrm{~mL}$ demineralized water), (III) ammonium molybdate solution $\left(20 \mathrm{~g}\left(\mathrm{NH}_{4}\right)_{6} \mathrm{Mo}_{7} \mathrm{O}_{24} \times 4 \mathrm{H}_{2} \mathrm{O}\right.$ in $500 \mathrm{~mL}$ demineralized water) and (IV) ascorbic acid solution (1.76 $\mathrm{g}$ ascorbic acid in $100 \mathrm{~mL}$ demineralized water). Molybdenum reagent $(\mathrm{V})$ was prepared by combining 2.5 $\mathrm{mL}$ (I), $0.25 \mathrm{~mL}$ (II), $0.75 \mathrm{~mL}$ (III) and $1.5 \mathrm{~mL}$ (IV). Sample $(100 \mu \mathrm{L}), 900 \mu \mathrm{L}$ demineralized water, $10 \mu \mathrm{L}$ (III) and 160 $\mu \mathrm{L}(\mathrm{V})$ were mixed. After incubating at $60^{\circ} \mathrm{C}$ for 15 minutes, absorption was measured at $880 \mathrm{~nm}$. 
Glucose, lactic acid and acetic acid concentrations were determined using HPLC (Shimadzu: LC-10AD pump, SIL-10AD auto-sampler, CTO-10AD oven, refractive index detector RID-20A, CBM-20A communication module): 10 $\mu \mathrm{L}$ of sample was injected on an Aminex HPX-87H column $(300 \mathrm{~mm} \times 7.8 \mathrm{~mm})$ and eluted isocratically with $0.4 \mathrm{~mL}$ minute $^{-1} 5 \mathrm{mM} \mathrm{H}_{2} \mathrm{SO}_{4}$ at $27^{\circ} \mathrm{C}$. For each analyte, calibration curves were generated with pure solutions of known concentration.

\section{RESULTS AND DISCUSSION}

\subsection{Hydrolysis}

DSS had a dry matter of $20.9 \pm 0.1 \%(\mathrm{w} / \mathrm{w})$ and based on dry weight an organic matter content of $72.5 \pm 0.1 \%(\mathrm{w} / \mathrm{w})$, a C-content of $35.9 \%(\mathrm{w} / \mathrm{w})$, a N-content of $5.6 \%(\mathrm{w} / \mathrm{w})$ and a C-to-N-ratio of 6.4. Protein, cellulose and hemicellulose contents (w/w) were 29.5, 14.7 and $18.5 \%$, respectively. Hydrolytic treatment with different concentrations of sulphuric acid was carried out to make nitrogen compounds, but also other nutrients available from DSS.

In Table 1 yields in mg of glucose, acetic acid, ammonium and phosphate per g DSS are shown. Glucose and acetic acid were released at yields of 0.28 and $0.33 \mathrm{mg}$, respectively, per g DSS when $1 \%(\mathrm{v} / \mathrm{v})$ sulphuric acid was used. Results revealed that the respective yields slightly decreased with decreasing sulphuric acid concentration (Table 1). The low yield of carbon compounds was expected beforehand and is explainable by the metabolization of easily accessible carbon sources during anaerobic digestion. The cellulose content in DSS can range between 88 and $150 \mathrm{mg} \mathrm{g}^{-1}$ (Metcalf, 1991) and is in agreement with the $147 \mathrm{mg} \mathrm{g}^{-1}$ found in this study. By the hydrolytic treatment, $28 \mathrm{mg} \mathrm{g}^{-1}$ glucose was released, and thus only a small fraction of hemicellulose and cellulose was degraded after the treatment $1 \%(\mathrm{v} / \mathrm{v})$ sulphuric acid. A harsher treatment in form of increased acid concentration, higher temperature and/or longer reaction time, however, was skipped to avoid a degradation of amino acids.

While it was possible to quantify carbon compounds which have been released from DSS, the quantification of free amino nitrogen compounds was hindered by the complex composition of hydrolysates. For sewage sludge a nitrogen content of $15-40 \mathrm{mg} \mathrm{g}^{-1}$ and for DSS $16-60 \mathrm{mg} \mathrm{g}^{-1}$ was found (Metcalf, 1991). The material used in this study contained $56 \mathrm{mg} \mathrm{g}^{-1}(5.6 \%$, w/w) nitrogen, which agrees with the reported values and represents a protein content of $295 \mathrm{mg} \mathrm{g}^{-1}(29.5 \%, \mathrm{w} / \mathrm{w})$. The release of ammonium ranged from minimum $1.16 \mathrm{mg} \mathrm{g}^{-1}$ using $0.1 \%(\mathrm{v} / \mathrm{v})$ to max-

TABLE 1: Yield of compounds obtained after hydrolysis of DSS in $0 \%(A), 0,1 \%(B), 0.2 \%(C), 0.5 \%(D)$ or $1 \%(E)$ (v/v) sulphuric acid.

\begin{tabular}{l|c|c|c|c|c}
\hline mg g $^{-1}$ & A & B & C & D & E \\
\hline Glucose & 0.14 & 0.16 & 0.16 & 0.21 & 0.28 \\
\hdashline Lactic acid & 0 & 0.22 & 0.05 & 0 & 0 \\
\hdashline Acetic acid & 0.13 & 0.17 & 0.12 & 0.23 & 0.33 \\
\hdashline Ammonium & 1.39 & 1.16 & 1.34 & 1.61 & 1.56 \\
\hline Phosphate & 8.63 & 9.65 & 8.79 & 10.72 & 9.42 \\
\hline
\end{tabular}

imum $1.61 \mathrm{mg} \mathrm{g}^{-1}$ using $0.5 \%$ (v/v) sulphuric acid. It should however be admitted that already $1.39 \mathrm{mg} \mathrm{g}^{-1}$ ammonium was obtained when DSS was soaked in water and thermally treated (Table 1).

In parallel to carbon and nitrogen compounds also phosphate was released. Phosphate in digested sewage sludge was already solubilized when DSS was soaked in water and thermally treated (Table 1). Irrespective the treatment, $7.10 \mathrm{mg} \mathrm{g}^{-1}$ was released which indicates the unnecessity of acid treatment for phosphate release. DSS contains around 15-40 $\mathrm{mg} \mathrm{g}^{-1} \mathrm{P}_{2} \mathrm{O}_{5}$ (Metcalf, 1991). Even though the phosphorous content is dependent on the material used it can be assumed that a considerable fraction has been released in this study. To obtain $80-90 \%(w / w)$ of phosphorous, Falayi recommends a treatment for 120 minutes using $8 \mathrm{M} \mathrm{KOH}, 95^{\circ} \mathrm{C}$ and a solid-to-liquid-ratio of 4 (Falayi, 2019).

\subsection{Fermentations}

In Figure $1 \mathrm{~A}$ and $\mathrm{B}$ is shown the production of lactic acid in two fermentations carried out under pH-uncontrolled conditions using DSS hydrolysate and one fermentation without hydrolysate as control (Figure 1C). When DSS hydrolysate was mixed with $10 \mathrm{~g} \mathrm{~L}^{-1}$ glucose lactic acid concentration increased from 1 to around $4 \mathrm{~g} \mathrm{~L}^{-1}$ and glucose was completely consumed after 48 hours, while the optical density increased slightly and the $\mathrm{pH}$ decreased from 6.9 to around 3.7 (Figure $1 \mathrm{~A}$ and $\mathrm{B}$ ). The concentration of acetic acid did only marginally change by the activity of acetogenic bacteria present in the inoculum and remained below $0.25 \mathrm{~g} \mathrm{~L}^{-1}$ (Figure 1A) or was not formed at all in the repeated fermentation (Figure 1B). Contrarily, the absence of DSS hydrolysate resulted in a reduced formation of lactic acid (increase from 1 to $2 \mathrm{~g} \mathrm{~L}^{-1}$ ) and consumption of glucose (from 10 to $5 \mathrm{~g} \mathrm{~L}^{-1}$ ) after 48 hours. The $\mathrm{pH}$ decreased from 6.9 to 4.2. Acetic acid was not present and the optical density (Figure 1C) was below the optical densities found in fermentations carried out with hydrolysate (Figure $1 \mathrm{~A}$ and $\mathrm{B}$ ).

Figure 2 illustrates the repeated fermentative production of lactic acid using DSS hydrolysate under $\mathrm{pH}$-controlled conditions. Glucose concentration decreased from 10 to $0 \mathrm{~g} \mathrm{~L}^{-1}$, while lactic acid concentration increased from 1 to $10 \mathrm{~g} \mathrm{~L}^{-1}$ within 24 hours in both fermentations. No changes in optical density was noted, and thus around $90 \%$ of carbon from glucose was most likely converted into lactic acid. Acetic acid concentration differed between both fermentations shown in Figure 2. In one fermentation (Figure $2 \mathrm{~A}$ ) the concentration was constant at around $1.6 \mathrm{~g} \mathrm{~L}^{-1}$, while in the other fermentation (Figure 2B) the acetic acid concentration was $0.1 \mathrm{~g} \mathrm{~L}^{-1}$. The differences result from the application of different DSS hydrolysate batches.

As a general remark, ammonium concentration was in all fermentations between 1.4 and $1.8 \mathrm{~g} \mathrm{~L}^{-1}$ and did not change over time (data not shown). It should be noted that an inhibition of bacteria by a high concentration of ammonium nitrogen, as observed in anaerobic digestion, can be excluded (Liu et al., 2018). The tolerance of lactic acid bacteria regarding high ammonium nitrogen concentration is an asset for the application of DSS as nitrogen source. 

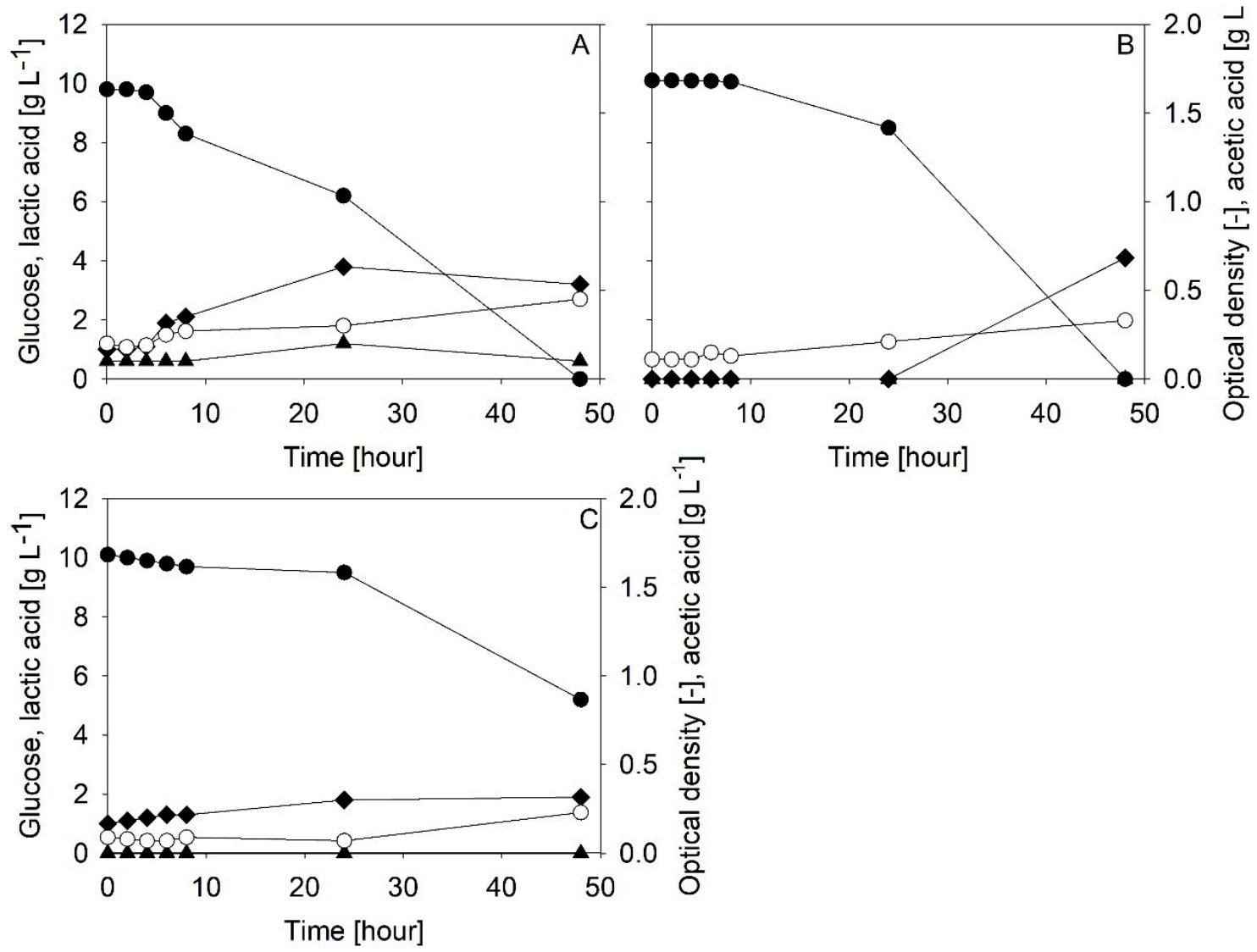

FIGURE 1: Time profiles in glucose (closed circle), acetic acid (closed triangle) and lactic acid (closed diamond) concentrations as well as optical density (open circle) in fermentations carried out under pH-uncontrolled conditions using DSS hydrolysate and inoculum (A and B) and without hydrolysate (C) as control.
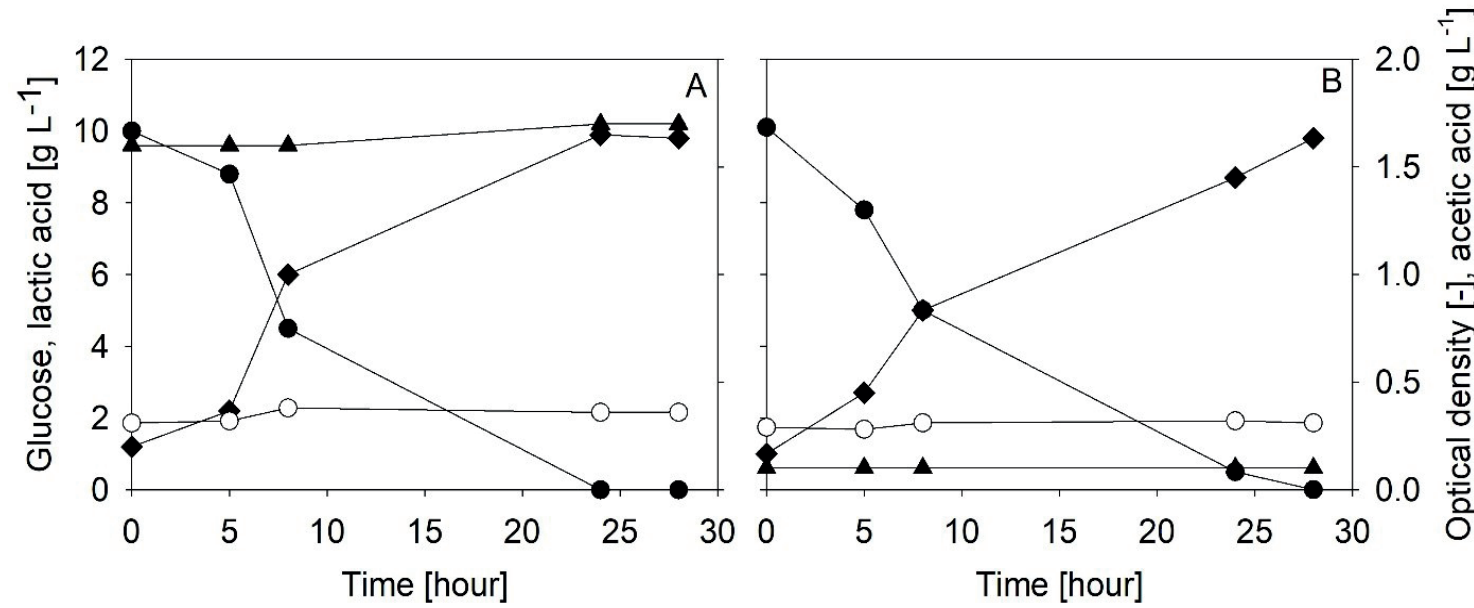

FIGURE 2: Time profiles in glucose (closed circle), acetic acid (closed triangle) and lactic acid (closed diamond) concentrations as well as optical density (open circle) in two fermentations ( $\mathrm{A}$ and $\mathrm{B}$ ) carried out under pH-controlled conditions using DSS hydrolysate and inoculum.

The formation of lactic acid is predominantly associated to the growth of lactic acid bacteria. Berry et al. (1999) reported from defined cultures of Lactobacillus rhamnosus lactic acid constants of 0.389 moles per gram growing cells, while only 0.0025 moles per gram were formed by non-growing cells. The supply of a nitrogen source which is cost-efficient and useable by lactic acid bacteria is therefore essential to achieve high productivities. Dietz et al.
(2016) applied alfalfa green juice as nitrogen source and obtained a yield of $0.69 \mathrm{~g}$ lactic acid $\mathrm{g}^{-1}$ glucose in batch fermentation. It is of interest for further process development that the juice was not further pre-treated or supplemented with other nutrients, and thus could be directly applied. However, Dietz et al. (2016) admitted that differences in alfalfa culture conditions (e.g., environmental and soil conditions) may have an impact on the nitrogen con- 
tent of juice and this aspect needs further investigation. To illuminate this aspect, Papendiek and Venus (2014) used the juice of legumes grown at different locations and harvested at different times of the year as nitrogen source in lactic acid fermentation. They found not only considerable differences in protein content in legumes but also differences up to $40 \%$ and $60 \%$ in lactic acid yield between study sites and sampling dates, respectively. Ma et al. made use of the high protein and carbohydrate contents of waste activated sludge to substitute yeast extract in lactic acid fermentation (Ma et al., 2014). In their experiments the yield of lactic acid per $\mathrm{g}$ glucose was 0.97 and the final titer 96.7 $\mathrm{g} \mathrm{L}^{-1}$ after 48 hours when $7 \mathrm{~g} \mathrm{~L}^{-1}$ hydrolyzed sewage sludge and $100 \mathrm{~g} \mathrm{~L}^{-1}$ glucose were applied. An application of DSS, however, has not been investigated. Generally, the applicability of DSS as nitrogen source in lactic acid fermentation is given. The control fermentation carried out without DSS resulted only in the formation of around $1 \mathrm{~g} \mathrm{~L}^{-1}$ lactic acid. In the control, microorganisms may have consumed remaining nitrogen originating from the food waste inoculum. However, it should be admitted that also wastewater exhibits seasonal variations in concentration of nitrogen compounds. Tuncal et al. (2009) detected a difference in mean concentrations of total nitrogen between summer and winter of $8.9 \mathrm{mg} \mathrm{L}^{-1}$. Therefore, further investigations using DSS obtained at different seasons are needed to assess whether DSS is a suitable nitrogen source with constant quality throughout the year.

Results further revealed that lactic acid fermentation should not be carried out $\mathrm{pH}$-uncontrolled when DSS-hydrolysate is used. As seen in this study at a $\mathrm{pH}$ of 5 and below lactic acid bacteria seem inhibited (Figure 1). Similar observation was made by Darwin et al. (2018) and Peinemann et al. (2020) when $\mathrm{pH}$ dropped below 5. However, fermentation was effective at a controlled $\mathrm{pH}$ of 6.8 (Figure 2) and the yield of $0.9 \mathrm{~g} \mathrm{~g}^{-1}$ was comparable to the one found by Ma et al. using sewage sludge $\left(0.97 \mathrm{~g} \mathrm{~g}^{-1}, \mathrm{Ma}\right.$ et al., 2014) and higher compared to the yields obtained in presence of green biomass juice $\left(0.6-0.7 \mathrm{~g} \mathrm{~g} \mathrm{~g}^{-1}\right.$, Dietz et al., 2016; Papendiek and Venus, 2014). It should, however, be noted that a variation in $\mathrm{pH}$ can be used to steer the product portfolio. In a co-cultivation of yeast and lactic acid bacteria, for instance, the product can be steered towards ethanol at a $\mathrm{pH}$ below 5 , while lactic acid is formed at higher pH-values (Darwin et al., 2018; Peinemann et al., 2020).

Sewage sludge can be, contrarily to DSS, rich in carbohydrates and contents from 10 to $15 \%$ (w/w, Hu \& Wang, 2019; Maeda et al., 2009) have been reported. However, since it seems necessary to add an additional carbon source even though activated sewage sludge is used (Ma et al., 2014) it seems irrespective whether lactic acid formation is performed prior to or after anaerobic digestion.

\section{CONCLUSIONS}

DSS can be applied as nutrient source in $\mathrm{pH}$-controlled lactic acid fermentation. The potential as carbon source is due to low yields obtained rather limited. However, the hydrolysis of proteins in DSS provides organic nitrogen compounds usable by lactic acid bacteria and resulting in a decent conversion of glucose into lactic acid at a yield of around $0.9 \mathrm{~g} \mathrm{~g}^{-1}$. The combination with other organic feedstocks, such as food waste as carbon source, could result in cost-efficient fermentations. Further work is recommended on the investigation of the hydrolytic treatment to improve the recovery of nitrogen compounds available and to substitute sulphuric acid.

\section{REFERENCES}

Agabo-García, C., Pérez, M., Rodríguez-Morgado, B., Parrado, J., Solera, R. 2019. Biomethane production improvement by enzymatic pre-treatments and enhancers of sewage sludge anaerobic digestion. Fuel, 255, 115713.

Alves de Oliveira, R., Schneider, R., Vaz Rossell, C.E., Maciel Filho, R., Venus, J. 2019. Polymer grade I-lactic acid production from sugarcane bagasse hemicellulosic hydrolysate using Bacillus coagulans. Bioresource Technology Reports, 6, 26-31.

Berry, A.R., Franco, C.M.M., Zhang, W., Middelberg, A.P.J. 1999. Growth and lactic acid productionin batch culture of Lactobacillus rhamnosus in a defined medium. Biotechnology Letters, 21, 163-167.

Darwin, Cord-Ruwisch, R., Charles, W. 2018. Ethanol and lactic acod production from sugars and starch wastes by anaerobic acidification. Engineering in Life Sciences, 18, 635-642.

Dietz, D., Schneider, R., Papendiek, F., Venus, J. 2016. Leguminose green juice as an efficient nutrient for $\mathrm{I}(+)$-lactic acid production. Journal of Biotechnology, 236, 26-34.

Dupré, C., Burrows, H.D., Campos, M.G., Delattre, C., Encarnação, T., Fauchon, M., Gaignard, C., Hellio, C., Ito, J., Laroche, C., Legrand, J., Michaud, P., Pais, A.A.C.C., Pierre, G., Serive, B., Watanabe, M.M. 2020. Microalgal biomass of industrial interest: Methods of characterization. In: Handbook on Characterization of Biomass, Biowaste and Related By-products, 537-639.

Falayi, T. 2019. Alkaline recovery of phosphorous from sewage sludge and stabilisation of sewage sludge residue. Waste Management, 85, 166-172.

Glaser, R., Venus, J. 2018. Co-fermentation of the main sugar types from a beechwood organosolv hydrolysate by several strains of Bacillus coagulans results in effective lactic acid production. Biotechnology Reports, 18, e00245.

Günther, S., Grunert, M., Müller, S. 2018. Overview of recent advances in phosphorus recovery for fertilizer production. Engineering in Life Sciences, 18, 434-439.

Hu, Y., Wang, J. 2019. Biohydrogen production from co-fermentation of fallen leaves and sewage sludge. Bioresource Technology, 285, 121342.

Izaguirre, J.K., Dietrich, T., Villarán, M.C., Castañón, S. 2020. Protein hydrolysate from organic fraction of municipal solid waste compost as nitrogen source to produce lactic acid by Lactobacillus fermentum ATCC 9338 and Lactobacillus plantarum NCIMB 8826. Process Biochemistry, 88, 15-21.

Juturu, V., Wu, J.C. 2016. Microbial production of lactic acid: The latest development. Critical Reviews in Biotechnology, 36(6), 967-977.

Klotz, S., Kaufmann, N., Kuenz, A., Prüße, U. 2016. Biotechnological production of enantiomerically pure d-lactic acid. Applied Microbiology and Biotechnology, 100(22), 9423-9437.

Li, J., Zhang, W., Li, X., Ye, T., Gan, Y., Zhang, A., Chen, H., Xue, G., Liu, Y. 2018. Production of lactic acid from thermal pretreated food waste through the fermentation of waste activated sludge: Effects of substrate and thermal pretreatment temperature. Bioresource Technology, 247, 890-896.

Liu, S., Yang, X., Yao, X. 2018. Impacts of ammonia nitrogen on autothermal thermophilic microaerobic digestion for sewage sludge treatment. Chemosphere, 213, 268-275.

Liu, W., Yang, H., Ye, J., Luo, J., Li, Y.-Y., Liu, J. 2020. Short-chain fatty acids recovery from sewage sludge via acidogenic fermentation as a carbon source for denitrification: A review. Bioresource Technology, 311, 123446.

López-Gómez, J.P., Alexandri, M., Schneider, R., Latorre-Sánchez, M., Coll Lozano, C., Venus, J. 2020. Organic fraction of municipal solid waste for the production of L-lactic acid with high optical purity. Journal of Cleaner Production, 247, 119165. 
Ma, K., Maeda, T., You, H., Shirai, Y. 2014. Open fermentative production of I-lactic acid with high optical purity by thermophilic Bacillus coagulans using excess sludge as nutrient. Bioresource Technology, 151, 28-35.

Maeda, T., Yoshimura, T., Shimazu, T., Shirai, Y., Ogawa, H. 2009. Enhanced production of lactic acid with reducing excess sludge by lactate fermentation. Journal of Hazardous Matter, 168, 656-663.

Martín, C., Peinemann, J.C., Wei, M., Stagge, S., Xiong, S., Jönsson, L.J. 2019. Dilute-sulfuric acid pretreatment of de-starched cassava stems for enhancing the enzymatic convertibility and total glucan recovery. Industrial Crops and Products, 132, 301-310.

Masutani, K., Kimura, Y. 2015. PLA synthesis. From the monomer to the polymer. RSC Polymer Chemistry Series, 3-36.

Metcalf. 1991. Wastewater engineering: Treatment, disposal and reuse. Metcalf Eddy Inc.

Papendiek F., Venus J. 2014. Cultivation and fractionation of leguminoses biomass for lactic acid production. Chemical and Biochemical Engineering Quarterly, 28, 375-382

Peinemann, J.C., Rhee, C., Shin, S.G., Pleissner, D. 2020. Non-sterile fermentation of food waste with indigenous consortium and yeast - Effects on microbial community and product spectrum. Bioresource Technology, 306, 123175
Pleissner, D. 2019. Assessment of upstr.,eam bioprocessing, 3 Biotech, 9,260

Raheem, A., Sikarwar, V.S., He, J., Dastyar, W., Dionysiou, D.D., Wang, W., Zhao, M. 2018. Opportunities and challenges in sustainable treatment and resource reuse of sewage sludge: A review. Chemical Engineering Journal, 337, 616-641.

Schnell, M., Horst, T., Quicker, P. 2020. Thermal treatment of sewage sludge in Germany: A review. Journal of Environmental Management, 263, 110367

Tuncal, T., Pala, A., Uslu, 0. 2009. Determination of microbial responses to seasonla variations of wastewater compostion in the Izmir wastewater treatment plant. Fresenius Environment Bulletin, 18, 2114-2122.

van Velthuijsen, J.A. 1996. Lactic acid production and utilization. In: Carbohydrates as Organic Raw Materials III, 129-140.

Vega-Mas, I., Sarasketa, A., Marino, D. 2015. High-throughput quantification of ammonium content in Arabidopsis. Bio-Protocol, 5.

Yang, G., Wang, J. 2019. Biohydrogen production by co-fermentation of sewage sludge and grass residue: Effect of various substrate concentrations. Fuel, 237, 1203-1208.

Yang, G., Wang, J. 2017. Co-fermentation of sewage sludge with ryegrass for enhancing hydrogen production: Performance evaluation and kinetic analysis. Bioresource Technology, 243, 1027-1036. 